\title{
Evaluasi Kesesuaian Lahan Tanaman Kacang Tanah (Arachis hipogeae L.) di Desa Werwaru Kecamatan Pulau Moa
}

\section{Land Suitability Evaluation for Peanut Plants (Arachis hipogeae L.) in the Werwaru Village of Moa Island Sub-District}

\section{Marlin J. Oraplawal, Johanis P. Haumahu*, dan Robby G. Risamasu}

\author{
Jurusan Budidaya Pertanian, Fakultas Pertanian, Universitas Pattimura, Jl. Ir. M. Puttuhena, Kampus Poka \\ Ambon 97233 \\ *Penulis Korespondensi: e-mail: agro82040@gmail.com
}

\begin{abstract}
This study was aimed to determine the limiting factors for peanut plants found in the field and establish land suitability class for peanuts in Werwaru Village, Moa Island Sub-District Western South Maluku District. The method used in this research was survey method. Distance observation was free survey, by using identification observation type (boring), and pit profile. Based on the actual land suitability assessment, it was known that in the research location there were several characteristic and quality factors of the land that became the limiting factors on the growth of peanut crops, i.e: rainfall factor during growth period (wa), effective depth ( $r$ ), C-organic ( $n r)$, slope ( $s$ ). Based on the land area improvement action for peanut crops were in the $S 2$ and $S 3$ classes. The recommended land units for peanut plants were: for class S2: LOa1D, LOa3A, LOa3B, LOa3C, LOa3D, L1a1D, L1a3B, L2a1D, L2a3B with area 1942,13 ha or 36.1 percent and S3: LOa2E, L1a2E, L2a2E covering an area of 219.12 ha or 4.1 percent.
\end{abstract}

Keywords: evaluation of land suitability, peanuts, Werwaru Moa Island

\section{ABSTRAK}

Penelitian ini bertujuan untuk menentukan factor-faktor pembatas untuk tanaman kacang tanah yang terdapat di lapangan dan menetapkan kelas kesesuaian lahan untuk tanaman kacang tanah di desa Werwaru Kecamatan Pulau Moa Kabupaten Maluku Barat Daya. Metode yang digunakan dalam penelitian ini adalah metode survey. Jarak observasi yang digunakan adalah free survey, dengan menggunakan tipe pengamatan identifikasi (boring), dan profil pit. Berdasarkan hasil penilaiaan kesesuaian lahan aktual diketahui bahwa pada lokasi penelitian terdapat beberapa faktor karakteristik dan kualitas lahan yang menjadi faktor pembatas terhadap pertumbuhan tanaman kacang tanah yakni: faktor curah hujan pada masa pertumbuhan (wa), kedalaman efektif (r), C-organik (nr), Kemiringan lereng (s). Berdasarkan tindakan perbaikan satuan lahan yang direkomendasikan untuk tanaman kacang tanah yaitu pada kelas S2 dan kelas S3. Satuan lahan yang direkomendasikan untuk tanaman kacang tanah yakni: Untuk kelas S2: L0a1D, L0a3A, L0a3B, L0a3C, L0a3D, L1a1D, L1a3B, L2a1D, L2a3B dengan luas 1942,13 ha atau 36,1 persen dan S3: L0a2E, L1a2E, L2a2E dengan luas 219,12 ha atau 4,1 persen.

Kata kunci: evaluasi kesesuaian lahan, kacang tanah, Werwaru Pulau Moa

\section{PENDAHULUAN}

Lahan mempunyai potensi yang berbeda dalam mendukung pertumbuhan dan perkembangan dari suatu tanaman. Untuk itu evaluasi kesesuaian lahan untuk penggunaan pertanian secara luas sangat diperlukan sehingga dapat di peroleh suatu lahan yang cocok untuk pertumbuhan dan perkembangan tanaman pertanian menurut kesesuaiannya. Penggunaan lahan sesuai jenis tanamannya dapat dioptimalkan dengan pendekatan evaluasi kesesuaian lahannya (Astuti, 2010). Evaluasi kesesuian lahan dilakukan dengan metode matching yaitu dengan mencocokkan serta memperbandingkan antara data karakteristik lahan dari lapangan dan laboratorium dengan kriteria kesesuaian lahan untuk tanaman padi sawah (Balai Penelitian Tanah, 2003). Secara spesifik, kesesuain lahan untuk suatu komoditas dinilai berdasarkan sifat-sifat fisik lingkungan, seperti tingkat kesuburan tanah, iklim, topografi, hidrologi dan draenase Supriyadi et al. (2009) dalam Mutiara (2015).

Sumarno (1987) dalam Astuti (2010) mengatakan bahwa tanaman kacang tanah merupakan komoditas yang menguntungkan, dengan masukan yang lebih rendah. Usaha budidaya kacang tanah memberikan prospek yang sangat baik, karena luasnya pasaran hasil kacang tanah. Jika dilihat dari data Hasil Laporan 
Statistik Pertanian (SP) Tanaman Pangan BPS, Produksi Kacang Tanah Menurut Provinsi (ton) tahun 2013-2017 untuk Provinsi Maluku cenderung mengalami penurunan dari tahun 2013-2015 namun pada dua tahun terakhir sudah mengalami peningkatan hingga ditahun 2017 produksi kacang tanah di Provinsi Maluku sebesar 1.480 ton. Untuk lebih menjaga kestabilan produksi kacang tanah perlu dilakukan suatu langkah tepat untuk mengembangkan budidaya tanaman kacang tanah agar produksi kacang tanah bisa tetap meningkat tiap tahunnya. Langkah yang perlu dilakukan yaitu dengan melakukan evaluasi kesesuaian lahan untuk tanaman kacang tanah, sehingga diharapkan dapat membantu masyarakat/petani dalam usaha pengembangan kacang tanah untuk meningkatkan produksi tanaman.

Desa Werwaru merupakan salah satu desa pada Kecamatan Pulau Moa Kabupaten Maluku Barat Daya. Di Desa Werwaru terdapat satu jenis kacang tanah spesifik lokasi yang dikenal dengan nama Kacang Laga. Keunggulan dari kacang ini yaitu mempunyai ukuran polong dan biji yang lebih besar bila dibandingkan dengan kacang tanah pada umumnya. Di Pulau Moa, kacang dengan polong besar ini hanya terdapat di Desa Werwaru dan ada juga terdapat di Pulau Leti. Kacang ini dapat dipanen setelah berumur 127-130 hst (Susanto, 2011). Mengingat ketersediaan data (tanah, topografi, penggunaan lahan), peta-peta dasar masih bersifat umum dan belum tersedia secara detail sehingga perlu untuk melakukan kajian terkait dengan kondisi daerah dimaksud untuk pengembangan tanaman kacang tanah yang jika dilihat dari faktor iklim (suhu udara, kelembaban, dan lamanya penyinaran matahari) sangat baik untuk pertumbuhan tanaman kacang tanah. Penelitian ini bertujuan untuk Menentukan faktor-faktor pembatas untuk tanaman kacang tanah (Arachis hypogeae L.) yang terdapat di lapangan, dan menetapkan kelas kesesuaian lahan untuk tanaman kacang tanah di desa Werwaru Kecamatan Pulau Moa.

\section{METODE PENELITIAN}

Penelitian ini dilaksanakan di Desa Werwaru, Kecamatan Pulau Moa, Kabupaten Maluku Barat Daya, Provinsi Maluku pada bulan Agustus 2017 sampai selesai. Metode yang digunakan dalam penelitian ini adalah metode survey. Jarak observasi yang digunakan adalah free survey, dengan menggunakan tipe pengamatan identifikasi (boring), dan profil pit.

Bahan yang digunakan adalah Peta kerja lapang skala 1: 20.000 (hasil interpretasi ArcGIS), serta bahanbahan untuk pekerjaan lapangan antara lain: $\mathrm{H}_{2} \mathrm{O}_{2}, \mathrm{HCl}$, dan $\mathrm{H}_{2} \mathrm{O}$. Alat yang digunakan dalam penelitian ini adalah Global Positioning System (GPS), altimeter, abney level, bor tanah, pisau lapang, pacul, sekop, meter rol, tali, buku pengamatan, kartu diskripsi, buku munsel soil color chart, doctor plant (untuk mengukur $\mathrm{pH}$ dan kandungan bahan organik secara kualitatf dan alat tulis menulis.

\section{Pelaksanan Penelitian}

Tahap pekerjaan lapangan dalam penelitian ini meliputi: 1) diskusi pada tingkat desa (kepala desa dan pemuka masyarakat; 2) pengisian kuesioner untuk petani; 3) pengecekan lapangan dengan metode survei lapangan; dan 4) pengamatan aspek fisik lahan (bentuk wilayah, jenis tanah, keadaan iklim, jenis dan potensi tanaman kacang tanah) sosial ekonomi (produksi dan pemasaran, kelembagaan di desa dan peranannya) dan sosial budaya (pola usaha tani).

\section{HASIL DAN PEMBAHASAN}

\section{Kondisi Fisik Wilayah}

Secara administratif lokasi penelitian termasuk dalam Kecamatan Pulau Moa serta memiliki luas areal secara keseluruhan sebesar 5327,97 ha dengan 25,52 ha sebagai areal pemukiman.

Hasil penelitian lapangan menunjukkan bahwa topografi atau bentuk wilayah pada kawasan Desa Werwaru termasuk di dalam kategori dataran sampai agak berbukit rendah dengan ketinggian dari muka laut kurang dari 50 meter. Sedangkan untuk fisiografi secara mikro (micro relief) dan presentase kelerengan terdiri atas tiga kategori yakni datar (0-3\%) dengan luas 5135.40 ha atau $96,39 \%$, landai (3-8\%) dengan luas 160,09 ha atau $3,0 \%$ dan bergelombang $(8-15 \%)$ dengan luas 32,48 ha atau $0,61 \%$.

Hasil analisis kondisi iklim pada lokasi penelitian selama 10 tahun pengamatan, ditemukan ratarata curah hujan tertinggi sebesar $334,13 \mathrm{~mm}$ terjadi pada bulan April dan rata-rata curah hujan terendah sebesar 35,52 mm terjadi pada bulan Agustus. Menurut Oldeman (1975), lokasi penelitian termasuk iklim C3 karena memiliki 6 bulan basah yaitu bulan dengan curah hujan > $200 \mathrm{~mm}$ terjadi pada bulan Desember s.d. Juni dan bulan kering 5 bulan yaitu bulan dengan curah hujan < $100 \mathrm{~m}$ terjadi pada bulan Juli s.d. November.

Menurut Pusat Penelitian dan Pengembangan Geologi (1994), di Desa Werwaru hanya mecakup satu formasi geologi yaitu Formasi Batu Gamping Klastik (Qgp). Berdasarkan hasil pengamatan lapangan, lokasi penelitian terdiri atas tujuh tipe penggunaan lahan yaitu: Pemukiman, Pertanian Lahan Kering Campuran, Semak Belukar, Savanna atau Padang Rumput, Hutan Lahan Kering Sekunder, Lapangan Terbang dan Tempat Pembuangan Akhir.

Klasifikasi tanah yang ditemukan di lokasi penelitian dilakukan berdasarkan Sistem Klasifikasi Tanah menurut Pusat Penelitian Tanah (Subardja et al., 2014) dengan pendekatannya menurut Sistem Taksonomi Tanah (USDA, 2014). Berdasarkan hasil Pengamatan tanah di lapangan yang dilakukan melalui pengamatan boring dan profil tanah, ditemukan tiga jenis tanah yaitu: Litosol (Usthorthents), Renzina (Haprendolls), dan Molisol (Eutrudepts). 


\section{Kualitas/karakteristik Satuan Lahan}

\section{Karakteristik Fisik Satuan Lahan}

Drainase tanah menunjukkan kecepatan meresapnya air dari tanah, atau keadaan yang menunjukkan lama dan seringnya jenuh air. Drainase tanah yang ditemukan di daerah Penelitian yaitu drainase baik. Drainase tanah baik yaitu air dapat mudah meresap ke dalam massa tanah tetapi tidak secara cepat. Air tanah pada umumnya sangat dalam. Ciri yang dapat diketahui di lapangan, yaitu tanah berwarna homogen tanpa bercak atau karatan besi dan mangan serta warna agley (reduksi). Tekstur tanah merupakan perbandingan fraksi pasir, debu dan liat dalam massa tanah yang ditentukan di laboratorium. Tekstur tanah daerah penelitian terdiri atas agak halus sampai halus. Tekstur tanah agak halus sampai halus dijumpai pada tanah Litosol (Usthorthents), Renzina (Haprendolls), dan Molisol (Eutrudepts).

Kedalaman efektif tanah adalah kedalaman dimana perakaran tanaman masih bisa masuk ke dalam tanah. Kedalaman tersebut umumnya dibatasi oleh suatu lapisan penghambat. Kedalaman efektif yang di temukan di daerah Penelitian yaitu sangat dangkal sampai dalam. Hal ini ditunjukkan dengan ke dalaman solum tanah yang ditemukan sangat dangkal. Umumnya kelerengan yang ditemukan di daerah Penelitian termasuk datar sampai bergelombang, dengan kelerengan berkisar dari 0-3\%, 3-8\%, dan 8-15\%.

Erosi hampir tidak ditemukan di daerah Penelitian karena kondisi daerah penelitian didominasi oleh bentuk wilayah datar dengan kemiringan lereng 0 $3 \%$. Lokasi-lokasi yang solum tanah sangat dangkal itu disebabkan oleh kondisi geologi (batu gamping koral) yang lebih dominan muncul dipermukaan sehingga penutup lahan atau vegetasi lebih banyak ditumbuhi oleh rumput dan semak.

Kondisi umum daerah penelitian untuk Desa Werwaru umumnya didominasi oleh batu gamping koral yang ditemukan berdasarkan hasil pengamatan lapangan sebagian besar menyebar ke arah Selatan (Desa Upunyor) dan ke arah Timur (Desa Klis). Sedangkan sebelah Utara hanya spot-spot yang terbentuk pada lokasi penelitian tersebut. Lokasi tersebut berdasarkan hasil penilaian kelas kesesuaian lahan termasuk tidak sesuai (N) untuk budidaya tanaman kacang tanah.

\section{Karakteristik dan Kualitas Kimia Satuan Lahan}

Hasil analsis $\mathrm{pH}$ tanah menunjukkan bahwa reaksi tanah-tanah di daerah Penelitian berkisar dari $\mathrm{pH}$ 6,7-7,0 atau bereaksi agak masam sampai netral. Tanaman pertanian umumnya akan tumbuh dan berkembang dengan baik pada kisaran $\mathrm{pH}$ 6,0 sampai 7,0 karena pada $\mathrm{pH}$ demikian unsur hara esensiel tersedia untuk memenuhi kebutuhan tanaman. Kandungan Bahan Organik tanah-tanah di daerah Penelitian termasuk sangat rendah sampai sangat tinggi. Kandungan bahan organik sangat rendah dijumpai pada tanah-tanah yang sudah mengalami kehilangan lapisan atas. Kehilangan lapisan atas ini akibat dari kebiasaan pertanian tradisonal yang dilakukan dengan cara membakar lahan, hal ini dapat mempengaruhi penurunan bahan organik karena pertanian yang dilakukan secara bergilir. Sedangkan kandungan bahan organik tinggi ditemukan pada tanah-tanah yang lapisan permukaan yang mempunyai vegetasi penutup masih sebagian didominasi oleh hutan.

Kandungan NPK yang ditentukan ini berdasarkan hasil pengukuran secara kualitatif di lapangan dengan menggunakan Doctor Plant. Hasil pengukuran menun-jukkan bahwa NPK tanah pada lokasi penelitian termasuk sangat rendah sampai sedang.

\section{Rekomendasi Tindakan Perbaikan Untuk Tiap Faktor Pembatas}

Berdasarkan hasil analisis kesesuaian lahan dilokasi menunjukkan bahwa di lokasi penelitian ditemukan kelas kesesuaian lahan, yaitu: kelas S2 (cukup sesuai), kelas S3 (sesuai marginal), dan kelas $\mathrm{N}$ (tidak sesuai), dengan faktor pembatas fisik lahan media perakaran (rc) dalam hal ini kedalaman tanah (r) dan bahaya erosi (eh) dalam hal ini kemiringan lereng (s). Jenis usaha perbaikan dari masing-masing faktor pembatas dapat dilihat pada Tabel 2.

Kelas kesesuaian lahan potensial untuk tanaman kacang tanah di Desa Werwaru

Penilaian kesesuaian lahan potensial merupakan analisis lanjutan dari penilaian sebelumnya (kesuaian aktual), dimana dilakukan upaya perbaikan/upaya pengelolaan lahan yang menjadi faktor pembatas kelas kesesuaian aktual. Penilaian kelas kesesuaian lahan untuk tanaman kacang tanah di Desa Werwaru dapat dilihat pada Tabel 3 .

\section{Aspek sosial budaya}

Di Desa Werwaru terdapat satu jenis kacang spesifik lokasi dengan keunggulan, polong besar dan daya adaptasi yang baik pada lahan kering. Kacang tanah ini awalnya dikembangkan di Pulau Leti dan oleh masyarakat dinamakan "Kacang Laga". Namun seiring berjalannya waktu masyarakat Pulau Leti mulai terarik untuk membudi-dayakan tanaman sayuran sehingga saat ini tidak banyak dari masyarakat Pulau Leti yang membudidayakan kacang tanah ini. Sejak tahun 1973 masyarakat Pulau Moa khususnya masyarakat Desa Werwaru mulai membawa bibit Kacang Laga yang oleh masyarakatDesaWerwaru dinamakan "Lawruru Wlade" untuk dibudidayakan di desa mereka. Lawruru Wlade berasal dari bahasa daerah. "Lawruru" berarti "kacang" dan "Wlade" berarti "orang luar negeri" sehingga Lawruru Wlade berarti kacang orang luar negeri. Pemerintah Kabupaten Maluku Barat Daya dalam hal ini Dinas Pertanian belum mengkonfirmasikan atau memastikan jenis dari kacang tanah ini secara nasional. 
Tabel 2. Jenis usaha perbaikan kualitas/karakteristik lahan aktual menjadi potensial menurut tingkat pengelolaannya di lokasi penelitian

\begin{tabular}{|c|c|c|c|}
\hline No & $\begin{array}{c}\text { Kualitas/ } \\
\text { Karakteristik Lahan }\end{array}$ & Jenis Usaha Perbaikan & $\begin{array}{c}\text { Tingkat } \\
\text { Pengelolaan }\end{array}$ \\
\hline 1 & $\begin{array}{l}\text { Ketersediaan air (wa) } \\
\text { - Curah hujan pada masa } \\
\text { pertumbuhan (w) }\end{array}$ & Tidak dapat dilakukan & - \\
\hline 2. & $\begin{array}{l}\text { Media perakaran (rc) } \\
\text { - Kedalaman efektif (r) }\end{array}$ & Tidak dapat dilakukan & - \\
\hline 3. & $\begin{array}{l}\text { Retensi hara (nr): } \\
\text { - C-Organik }\end{array}$ & Pemupukan & Rendah, sedang, tinggi \\
\hline 4. & $\begin{array}{l}\text { Bahaya erosi (eh) } \\
\text { - Kemiringan lereng (s) }\end{array}$ & $\begin{array}{l}\text { Usaha pengurangan laju erosi, } \\
\text { pembuatan teras, penanaman sejajar } \\
\text { kontur, penanaman tanaman } \\
\text { penutup tanah. }\end{array}$ & Sedang, tinggi \\
\hline
\end{tabular}

Tabel 3. Kelas Dan Faktor Pembatas Kesesuaian Lahan Aktual Dan Potensial Untuk Tanaman Kacang Tanah Di desa Werwaru

\begin{tabular}{|c|c|c|c|c|}
\hline No & $\begin{array}{l}\text { Kode } \\
\text { Satuan } \\
\text { Lahan }\end{array}$ & $\begin{array}{l}\text { Kesesuaian } \\
\text { Lahan Aktual } \\
\text { Tanaman } \\
\text { Kacang Tanah }\end{array}$ & $\begin{array}{c}\text { Faktor } \\
\text { Pembatas }\end{array}$ & $\begin{array}{l}\text { Kesesuaian Lahan } \\
\text { Potensial } \\
\text { Tanaman Kacang } \\
\text { Tanah } \\
\end{array}$ \\
\hline 1 & L0 a $1 \mathrm{D}$ & $\mathrm{S} 2 \mathrm{w}, \mathrm{nr}$ & $\begin{array}{c}\text { CH pada masa pertumbuhan (w) } 1100-1600 \mathrm{~mm} \text {, dan C- } \\
\text { org (nr) } 0,8-1,2 \%\end{array}$ & $\mathrm{~S} 2 \mathrm{w}$ \\
\hline 2 & L0 a $2 \mathrm{E}$ & $\mathrm{S} 3 \mathrm{r}$ & Kedalaman tanah (r) $25-50 \mathrm{~cm}$ & $\mathrm{~S} 3 \mathrm{r}$ \\
\hline 3 & LO a $3 \mathrm{~A}$ & $\mathrm{~S} 2 \mathrm{w}, \mathrm{r}, \mathrm{nr}$ & $\begin{array}{l}\mathrm{CH} \text { pada masa pertumbuhan (w) } 1100-1600 \mathrm{~mm} \text {, } \\
\text { kedalaman tanah (r) } 50-75 \mathrm{~cm} \text { dan C-org (nr) } 0,8-1,2 \\
\%\end{array}$ & $\mathrm{~S} 2 \mathrm{w}, \mathrm{r}$ \\
\hline 4 & L0 a 3 B & $\mathrm{S} 2 \mathrm{w}, \mathrm{r}$ & $\begin{array}{c}\mathrm{CH} \text { pada masa pertumbuhan (w) } 1100-1600 \mathrm{~mm} \text {, dan } \\
\text { kedalaman tanah (r) } 50-75 \mathrm{~cm}\end{array}$ & $\mathrm{~S} 2 \mathrm{w}, \mathrm{r}$ \\
\hline 5 & L0 a $3 \mathrm{C}$ & $\mathrm{S} 2 \mathrm{w}, \mathrm{r}$ & $\begin{array}{c}\text { CH pada masa pertumbuhan (w) } 1100-1600 \mathrm{~mm} \text {, dan } \\
\text { kedalaman tanah (r) } 50-75 \mathrm{~cm}\end{array}$ & $\mathrm{~N}$ \\
\hline 6 & L0 a $3 \mathrm{D}$ & $\mathrm{S} 2 \mathrm{w}, \mathrm{nr}$ & $\begin{array}{c}\mathrm{CH} \text { pada masa pertumbuhan (w) } 1100-1600 \mathrm{~mm} \text {, dan C- } \\
\operatorname{org}(\mathrm{nr}) 0,8-1,2 \%\end{array}$ & $\mathrm{~S} 2 \mathrm{w}$ \\
\hline 7 & $\mathrm{~L} 0$ a $4 \mathrm{~A}$ & $\mathrm{~N}$ & Kedalaman tanah $(\mathrm{r})<25 \mathrm{~cm}$ & $\mathrm{~N}$ \\
\hline 8 & LO a 4 B & $\mathrm{N}$ & Kedalaman tanah $(\mathrm{r})<25 \mathrm{~cm}$ & $\mathrm{~N}$ \\
\hline 9 & $\mathrm{LO}$ a $4 \mathrm{C}$ & $\mathrm{N}$ & Kedalaman tanah $(\mathrm{r})<25 \mathrm{~cm}$ & $\mathrm{~N}$ \\
\hline 10 & L0 a 4 D & $\mathrm{N}$ & Kedalaman tanah $(\mathrm{r})<25 \mathrm{~cm}$ & $\mathrm{~N}$ \\
\hline 11 & $\mathrm{LO}$ a $4 \mathrm{~F}$ & $\mathrm{~N}$ & Kedalaman tanah $(\mathrm{r})<25 \mathrm{~cm}$ & $\mathrm{~N}$ \\
\hline 12 & $\mathrm{~L} 0$ a $4 \mathrm{G}$ & $\mathrm{N}$ & Kedalaman tanah $(\mathrm{r})<25 \mathrm{~cm}$ & $\mathrm{~N}$ \\
\hline 13 & L1 a $1 \mathrm{D}$ & $\mathrm{S} 2 \mathrm{w}, \mathrm{nr}, \mathrm{s}$ & $\begin{array}{l}\mathrm{CH} \text { pada masa pertumbuhan (w) } 1100-1600 \mathrm{~mm} \text {, dan } \mathrm{C}- \\
\text { org (nr) } 0,8-1,2 \% \text {, kemiringan lereng (s) } 3-8 \%\end{array}$ & $\mathrm{~S} 2 \mathrm{w}, \mathrm{s}$ \\
\hline 14 & L1 a 2 E & $\mathrm{S} 3 \mathrm{r}$ & Kedalaman tanah (r) $25-50 \mathrm{~cm}$ & $\mathrm{~S} 3 \mathrm{r}$ \\
\hline 15 & L1 a 3 B & $\mathrm{S} 2 \mathrm{w}, \mathrm{r}, \mathrm{nr}, \mathrm{s}$ & $\begin{array}{l}\text { CH pada masa pertumbuhan (w) } 1100-1600 \mathrm{~mm} \text {, } \\
\text { kedalaman tanah (r) } 50-75 \mathrm{~cm}, \mathrm{C}-\mathrm{org}(\mathrm{nr}) 0,8-1,2 \% \text {, } \\
\text { dan kemiringan lereng (s) } 3-8 \%\end{array}$ & $\mathrm{~S} 2 \mathrm{w}, \mathrm{r}$ \\
\hline 16 & L1 a 4 B & $\mathrm{N}$ & Kedalaman tanah $(\mathrm{r})<25 \mathrm{~cm}$ & $\mathrm{~N}$ \\
\hline 17 & $\mathrm{~L} 1$ a $4 \mathrm{C}$ & $\mathrm{N}$ & Kedalaman tanah $(r)<25 \mathrm{~cm}$ & $\mathrm{~N}$ \\
\hline 18 & $\mathrm{~L} 2$ a $1 \mathrm{D}$ & $\mathrm{S} 3 \mathrm{~s}$ & Kemiringan lereng (s) 8-15\% & $\mathrm{S} 2 \mathrm{~s}$ \\
\hline 19 & $\mathrm{~L} 2$ a $2 \mathrm{E}$ & S3r,s & $\begin{array}{c}\text { Kedalaman tanah (r) } 25-50 \mathrm{~cm} \text {, kemiringan lereng (s) 8- } \\
15 \%\end{array}$ & S3r \\
\hline 20 & L2 a 3 B & S3s & Kemiringan lereng (s) 8-15\% & $\mathrm{S} 2 \mathrm{~s}$ \\
\hline 21 & L2 a 4 B & $\mathrm{N}$ & Kedalaman tanah $(\mathrm{r})<25 \mathrm{~cm}$ & $\mathrm{~N}$ \\
\hline 22 & $\mathrm{~L} 2$ a $4 \mathrm{C}$ & $\mathrm{N}$ & Kedalaman tanah $(\mathrm{r})<25 \mathrm{~cm}$ & $\mathrm{~N}$ \\
\hline
\end{tabular}



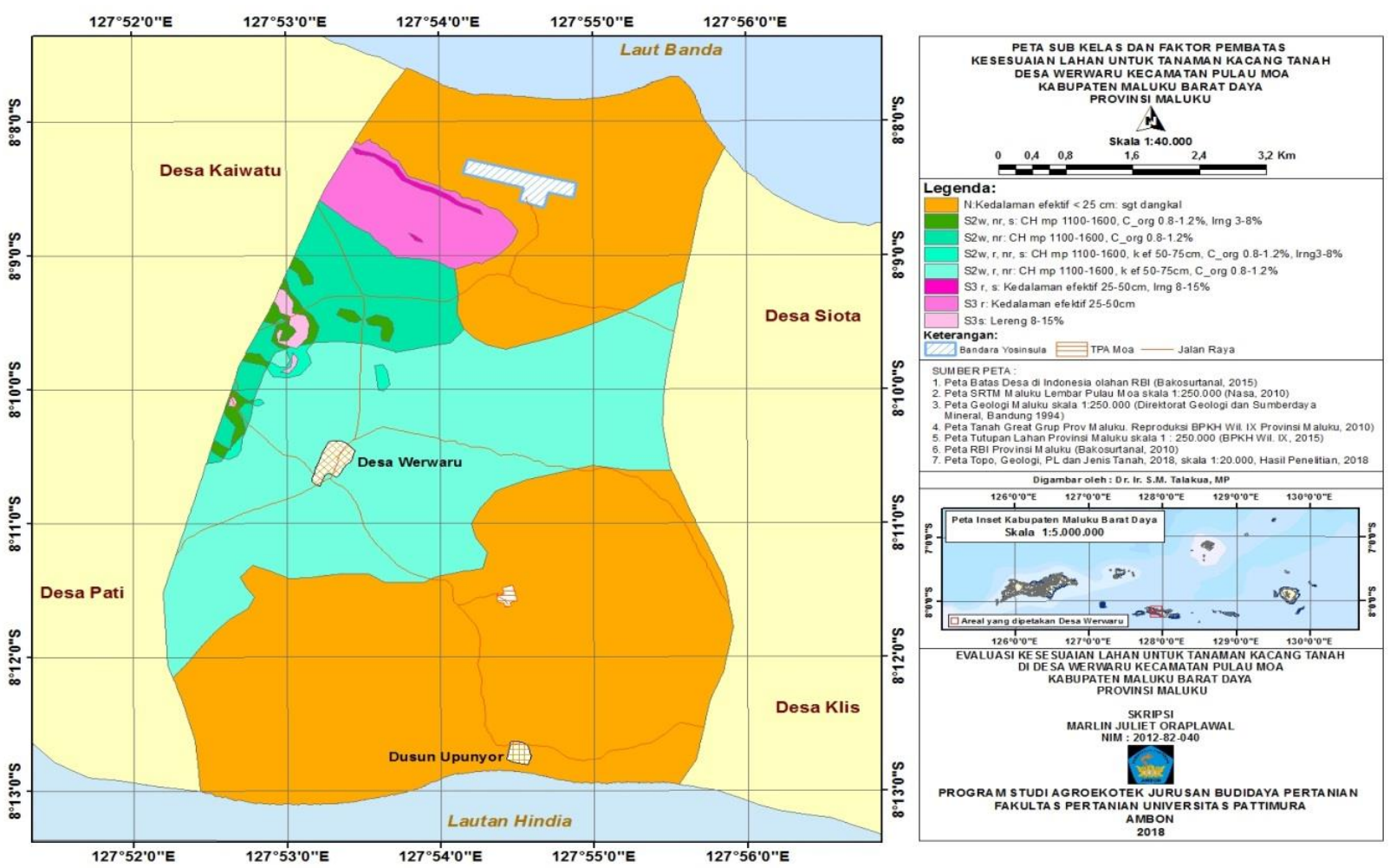

Gambar 1. Peta sub kelas dan faktor pembatas keseusaian lahan tanaman kacang tanah di Desa Werwaru.

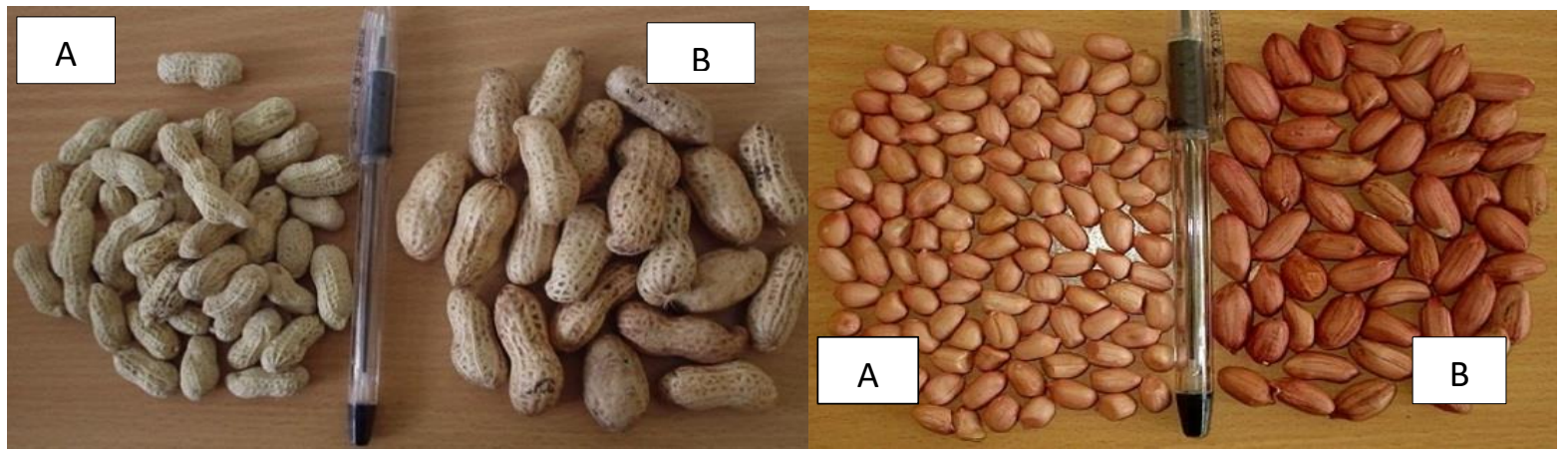

Gambar 2. Perbandingan kacang tanah biasa A dan kacang tanah Werwaru B, (Susanto, 2011)

Lahan yang digunakan masyarakat di Desa Werwaru sebagian besar pemanfaatannya lebih banyak pada pangan. Jenis tanaman pangan yang diusahakan oleh masyarakat setempat terdiri atas tanaman kacang tanah, jagung, dan uni kayu. Untuk tanaman kacang tanah luas panen tiap tahunnya sekitar 20,0 ha. Berdasarkan hasil pengamatan di lokasi penelitian luasan untuk penggunaan pertanian lahan kering campuran sebesar 1678,46 ha. Namun luasan tersebut belum dimanfaatkan secara maksimal oleh masyarakat, karena masih sekitar 50\% lahan yang belum dimanfaatkan.

Berdasarkan hasil wawancara di lokasi penelitian menunjukan bahwa ada beberapa lembaga kelompok tani yang masih menjalankan kegiatan pertanian. Pembentukan kelembagaan kelompok tani di Desa Werwaru sudah sejak lama dilakukan berdasarkam programprogram pemerintah dalam rangka pengembangan kapasitas petani dalam pelaksanaan kegiatan pertanian. Dengan berjalannya waktu, ada kelompok-kelompok tani yang mampu bertahan sampai sekarang, tetapi ada juga yang tidak dapat menuruskan kegiatan kelompok. Pada umumnya kelembagaan kelompok tani yang terbentuk di setiap desa di dasarkan pada pengembangan potensi pertanian di wilayah tersebut, yang bergerak pada sektor tanaman pangan.

Dalam hal pemasaran (dalam hal ini untuk tanaman) masyarakat Desa Werwaru tidak begitu mengalami kendala yang berarti hal ini dikarenakan peminat dari kacang tanah yang bgitu besar, hal ini dilihat ketika pada saat proses panen sudah terdapat beberapa pembeli yang langsung membeli di kebun. Para petani juga jarang untuk membawa hasil panen kacang mereka ke pasar, hal ini dikarenakan para konsumen yang langsung membeli di rumah-rumah para petani. 


\section{PENUTUP}

Berdasarkan hasil penelitian dan pembahasan, maka dapat disimpulkan bahwa:

1. Berdasarkan hasil penilaiaan kesesuaian lahan aktual diketahui bahwa pada lokasi penelitian terdapat beberapa faktor karakteristik dan kualitas lahan yang menjadi faktor pembatas terhadap pertumbuhan tanaman kacang tanah yakni: faktor ketersediaan air (w) dalam hal ini curah hujan, retansi hara (nr) dalam hal ini kandungan c-organik, media perakaran (r), dalam hal ini kedalaman tanah dan bahaya erosi (s) dalam hal ini kelerengan. Dari beberapa faktor pebatas yang sudah disebutkan di atas dapat dilakukan tindakan perbaikan dan terdapat beberapa satuan lahan yang dapat di tingkatkan kelas kesesuaian lahannya.

2. Tindakan perbaikan satuan lahan yang direkomendasikan untuk tanaman kacang tanah yaitu pada kelas S2 dan kelas S3. Satuan lahan yang direkomendasikan untuk tanaman kacang tanah yakni: Untuk kelas S2: L0a1D, L0a3A, L0a3B, L0a3C, L0a3D, L1a1D, L1a3B, , L2a1D, L2a3B dengan luas 1942,13 ha atau 36,1 persen dan S3: L0a2E, L1a2E, L2a2E dengan luas 219,12 ha atau 4,1 persen.

\section{DAFTAR PUSTAKA}

Astuti, F.D. 2010. Kesesuaian Lahan Untuk Tanaman Kacang Tanah (Arachis hypogeae L.) di Kecamatan Jatiyoso Kabupaten Karanganyar. Skripsi. Surakarta. Universitas Sebelas Maret.

Badan Pusat Statistik. 2015. Produksi Kacang Tanah Menurut Provinsi (ton) 1993-2015. http://www.pertanian.go.id/ap_pages/mod/datatp/ . Diakses: 27 April 2017.

Balai Penelitian Tanah. 2003. Petunjuk Teknis Evaluasi Lahan Untuk Komoditas Pertanian. Balai Penelitian Tanah. Bogor.

Mutiara, E. 2015. Kesesuaian lahan untuk tanaman kacang tanah di desa Sampuran, Kecamatan Ranto Baek Kabupaten Mandailing Natal. Jurnal Nasional Ecopedon 2: 001-004.

Subardja, D., S. Ritung, M. Anda, Sukarman, E. Suryani, dan R.E. Subandiono. 2014. Petunjuk Teknis Klasifikasi Tanah Nasional. Balai Besar Penelitian dan Pengembangan Pertanian. Bogor. 22 hal.

Susanto, A.N. 2011. Kacang laga si biji besar dari pulau Letti.

http://andrikonotosusanto.blogspot.co.id/? $m=1$. Diakses: 27 April 2017. 